\title{
Viability of Fresh and Frozen-Thawed Biopsied Bovine Embryos
}

\author{
By H. Gustafsson ${ }^{1}, \ddot{U}$. Jaakma ${ }^{2 *}$ and M. Shamsuddin ${ }^{2}$
}

${ }^{1}$ Swedish Association for Livestock Breeding and Production, Eskilstuna, and ${ }^{2}$ Department of Obstetrics and Gynaecology, Faculty of Veterinary Medicine, Swedish University of Agricultural Sciences, Uppsala, Sweden.

\begin{abstract}
Gustafsson H., U. Jaakma and M. Shamsuddin: Viability of fresh and frozen-thawed biopsied bovine embryos. Acta vet. scand. 1994, 35, 217-222. - Bovine embryos were biopsied using a simplified splitting technique and frozen-thawed according to a standard method with glycerol as cryoprotectant. The viability of fresh and frozen-thawed biopsied and intact embryos were evaluated after in vitro culture, by means of fluorescence test or following transfer to recipients. The survival rates after in vitro culture of fresh intact and biopsied embryos and of frozen-thawed intact and zona free embryos were not significantly different $(70 \%, 60 \%, 68 \%$ and $52 \%$, respectively), but significantly reduced for bipsied frozen-thawed embryos $(16 \%)(\mathrm{p} \leq 0.05)$. The pregnancy results after transfer of biopsied frozen-thawed embryos were also significantly lower $(8 \%)$ compared to fresh biopsied embryos $(39 \%)(\mathrm{p} \leq 0.05)$. Both intact and biopsied embryos fluoresced after incubation with diacetylfluorescin but with higher intensity for the intact embryos. It is suggested that the reduced survivability for the frozen-thawed biopsied embryos might be caused by combined effects of the loss of the zona pellucida and the reduction of cells as a result of the simplified biopsy technique. It is concluded that improved biopsy and/or freezing techniques must be used if biopsied embryos have to be frozen.
\end{abstract}

freezing; culture; fluorescence.

\section{Introduction}

Genotyping of bovine embryos prior to transfer to recipients has become realized due to the development of the polymerase chain reaction (PCR) technology. The determination of the sex is one application which already is in the beginning of practical use (Herr \& Reed 1991, Thibier \& Nibart 1992). Beside the technology related to the genotyping, the procedure also requires a series of embryo-technical manipulations like removal of cells (a

* Present address: Estonian Agricultural University, Dpt. of Reproduction Biology, Kreutzwaldi 1, EE2400 Tartu, Estonia. biopsy) from the embryo and storage of the biopsied embryo until transfer. The implications of the technology for commercial livestock production is to a high extent based on the simplicity of these procedures and the pregnancy results of the biopsied embryos following transfer.

There are several methods to biopsy embryos such as embryobisection (Bondioli et al. 1989), puncturing the zona pellucida and aspirating cells by a pipette (Schmidt et al. 1992a) or zona drilling where a small whole in the zona is created by enzymatic or acidic treatments and the biopsy cells are pushed out through this whole (Gordon \& Gang 1990). These methods require a complicated micro- 
manipulatory system which is impractical to handle under field conditions. A more practical method for routine biopsy of day-7 bovine embryos is described by Herr \& Reed (1991) where the biopsy is taken with a surgical blade controlled by only 1 micromanipulator.

Since the assay of the biopsy with current PCR methods will take 4-6 h, the possibility to freeze biopsied embryos would greatly increase the practical application of the method. However, embryos subjected to microsurgical operations are regarded to be more sensitive to cryopreservation than intact embryos ( Niemann 1991). Reduction in pregnancy rates following transfer of biopsied frozen-thawed day-7 embryos compared to intact embryos have varied between $0-20 \%$ (Schmidt et al. 1992, Picard et al. 1985, Bondioli et al. 1989, Nibart et al. 1989).

The aims of the present study were to biopsy bovine embryos by using a simplified method for embryobisection, to freeze them by a conventional method and evaluate their postthaw survival in vitro by vital fluorescence staining and after culture and in vivo following transfer to recipients.

\section{Materials and methods}

\section{Embryo collection}

Day-7 bovine embryos were nonsurgically collected from superovulated cows according to methods described by Albihn et al.(1989). Phosphate buffered saline (PBS, National Veterinary Institute, Uppsala, Sweden) supplemented with $1 \%$ fetal calf serum (FCS, National Veterinary Institute, Uppsala, Sweden) and kanamycin ( $25 \mu \mathrm{g} / \mathrm{l}$, Sigma Chemical CO, St Louis, USA) was used as flushing medium. The collected embryos were washed in the same medium and placed in sterile petridishes. Late morulae and early blastocysts classified as excellent or good were selected for biopsy.

\section{Micromanipulation}

The micromanipulation was accomplished with one Leitz micromanipulator under a stereomicroscope (Wild M-8, Heerbrugg, Germany) or with one Närtzhäuser micromanipulator under an inverted microscope (Leitz Dialux, Wetzlar, Germany). A microknife made by a piece of a razorblade (Gilette) was glued to a glass tube which was connected to the micromanipulator. The micromanipulator was adjusted for vertical movement. Two types of embryos were produced namely biopsied and zona free. An embryo to be biopsied was placed in a petri-dish containing pure PBS. After the embryo had settled on the bottom of the dish, the knife was placed at the top of the zona pellucida and towards the periphery of the embryo. The knife was then moved downwards through the zona pellucida and the embryo, splitting the embryo in a major and a minor part. The embryo and the biopsy were removed from the dish after addition of a small amount of FCS to the PBS.

Zonafree embryos were produced by splitting the zona avoiding to touch the embryo with the knife. If necessary the embryos were gently pressed out through the hole in the zona pellucida by the knife.

The micromanipulation of the embryos to be transferred fresh was performed under farm conditions in three different herds while embryos to be cultured or frozen were biopsied in the laboratory.

\section{Embryo freezing and thawing}

All types of embryos were washed in PBS and then put in freezing medium consisting of $10 \%$ (v/v) glycerol (The Pharmacy, The Royal Veterinary and Agricultural University, Copenhagen, Denmark) supplemented with FCS $(1 \% \mathrm{v} / \mathrm{v})$ and kanamycin $(25 \mu \mathrm{g} / \mathrm{ml})$. After equilibration of the embryos for $10 \mathrm{~min}$ in freezing medium at room temperature the 
embryos were aspirated into $0.25-\mathrm{ml}$ straws. The freezing procedure was carried out as cooling from $+15^{\circ} \mathrm{C}$ to $-7^{\circ} \mathrm{C}$ at a rate of $-5^{\circ} \mathrm{C} / \mathrm{min}$. Seeding at $-7^{\circ} \mathrm{C}$, freezing to $-37^{\circ} \mathrm{C}$ at a rate of $-0.3^{\circ} \mathrm{C} / \mathrm{min}$ and then plunging into liquid nitrogen. After storing in liquid nitrogen the straws were thawed in air and the embryos were placed in $1.0 \mathrm{M}$ sucrose ( The Pharmacy, The Royal Veterinary and Agricultural University, Copenhagen, Denmark) in PBS supplemented with FCS and kanamycin for $10 \mathrm{~min}$. The embryos were then washed in PBS supplemented with $10 \%$ FCS.

\section{Embryo culture}

The embryos were washed once in TCM 199 (Flow laboratories, Ayrshire, Scotland) supplemented with oestrous cow serum $(10 \%$ $\mathrm{v} / \mathrm{v})$, sodium pyruvate $(0.25 \mathrm{mM})$, penicillin $(50 \mathrm{IU} / \mathrm{ml})$ and streptomycin sulphate (50 $\mathrm{mg} / \mathrm{l})$ (ECS medium) and then co-cultured with bovine oviduct epithelial cells in $50-\mu \mathrm{l}$ droplets of ECS medium. Bovine oviduct cells (BOEC) were prepared according to the procedure described by Shamsuddin et al. (1993). Briefly, fresh oviduct cells were collected at slaughter, washed 5 times in low bicarbonate TALP (Parrish et al. 1988) and cultured in ECS medium. After 24 to $48 \mathrm{~h}$ of culture, the cells were washed twice with ECS medium by repeated centrifugation at $200 \mathrm{~g}$ for $10 \mathrm{~min}$, and the cell pellet was suspended with the same medium at a ratio of 1:400. Droplets of the cell suspension were prepared under prewarmed $\left(30^{\circ} \mathrm{C}\right)$ paraffin oil and incubated overnight. Survival of an embryo was considered by the evidence of formation of a distinct blastocoel or by expansion and hatching of blastocysts after $48 \mathrm{~h}$ of culture.

\section{FDA-staining and evaluation}

A stock solution of diacetylfluorescin (FDA), (EGA-Chemie, Steinheim, Germany) was prepared by dissolving FDA in acetone $(1 \mathrm{~g} / \mathrm{l})$. A working solution was made by adding $5 \mu \mathrm{l}$ of the stock solution to $2 \mathrm{ml}$ PBS. The embryos were incubated in this solution for 1 min and then put in PBS. The evaluation was made under a microscope (Leitz Dialux 20, Germany) fitted with reflected light fluorescence. Fluorescence was graded in the following manner: Grade 1, bright fluorescence; Grade 2, weak fluorescence; Grade 3, no fluorescence. The proportion of cells fluorescing was also estimated.

\section{Embryo transfer}

Embryos to be transferred were loaded into $0.25 \mathrm{ml}$ straws and transferred nonsurgically into synchronized recipients into the uterine horn ipsilateral to the ovary containing the corpus luteum. Pregnancy examination was carried out around 2 months after embryo transfer.

\section{Statistical analysis}

The data were analyzed statistically using chisquare test or Fishers test if less than 5 observations. The level of significance was $\mathrm{p} \leq 0.05$.

\section{Results}

\section{Micromanipulation}

Of the 94 embryos biopsied 35 were biopsied under farm conditions. The biopsy consisted of $10-30 \%$ of the embryo proper, and the time needed for the biopsy procedure ranged from 3 and $15 \mathrm{~min}$. The technique resulted in loss of the zona pellucida in 73 of the 94 biopsied embryos. The zona pellucida of the rest of the embryos had large openings.

Embryo culture, vital staining and embryo transfer

The viability of the not biopsied and biopsied fresh and frozen-thawed embryos and em- 
Table 1. Developmental rate of fresh and frozenthawed biopsied, intact and zona free embryos.

\begin{tabular}{llcc}
\hline & Treatment & $\begin{array}{c}\text { No. of } \\
\text { embryos } \\
\text { cultured }\end{array}$ & $\begin{array}{c}\text { No. of embryos } \\
(\%) \\
\text { developed }\end{array}$ \\
\hline Fresh & Intact & 20 & $14(70)^{\mathrm{a}}$ \\
& Biopsied & 20 & $12(60)^{\mathrm{a}}$ \\
$\begin{array}{l}\text { Frozen- } \\
\text { thawed }\end{array}$ & Intact & 41 & $28(68)^{\mathrm{a}}$ \\
& Biopsied & 32 & $5(16)^{\mathrm{b}}$ \\
& Zona-free & 21 & $11(52)^{\mathrm{a}}$ \\
\hline
\end{tabular}

a,b Figures in the same column with different subscripts are significantly different.

bryos with removed zona pellucida, based on development during in vitro culture, is shown in Table 1.

Representative samples of frozen-thawed intact $(n=7)$ and biopsied embryos $(n=7)$ was subjected to evaluation following FDA staining.

Fluorescence was emitted by 6 embryos of each category. The proportion of embryos scored to have bright fluorescence from more than $50 \%$ of the embryonic cells were $5 / 7$ and $3 / 7$ for intact and biopsied embryos respectively.

Pregnancy rates following transfer of fresh and frozen-thawed biopsied embryos are shown in Table 2.

\section{Discussion}

The present study shows that acceptable pregnancy results can be achieved following transfer of embryos that have been biopsied with a simple method under farm conditions but that the survivability of such embryos seems to be reduced following freezing-thawing with glycerol as cryoprotectant.

The biopsy method used minimized the equipment needed to a microscope and a microknife connected to one micromanipulator. This made it possible to perform the micro-
Table 2. Pregnancy rates after transfer of biopsied embryos.

\begin{tabular}{lccc}
\hline & $\begin{array}{c}\text { No. of } \\
\text { embryos } \\
\text { transferred }\end{array}$ & $\begin{array}{c}\text { No. of } \\
\text { animals } \\
\text { pregnant }\end{array}$ & $\begin{array}{c}\text { Pregnancy } \\
\text { rate \% }\end{array}$ \\
\hline Fresh & 23 & 9 & $39^{\mathrm{a}}$ \\
Frozen-thawed & 12 & 1 & $8^{\mathrm{b}}$ \\
\hline
\end{tabular}

a,b Figures in the same column with different subscripts are significantly different.

manipulation in temporary facilities (kitchen, coffee room) provided by the farm. However, the simplified biopsy method resulted in the loss of the zona pellucida and a rather large biopsy consisting of $10-30 \%$ of the embryo.

There were no difference in developmental capacity between biopsied embryos and intact embryos following in vitro culture. However the level of survival was overestimated using in vitro culture systems compared to survival after embryo transfer in agreement with other reports (Schmidt et al. 1992b).

The pregnancy rate obtained with fresh biopsied embryos (39\%) is in the range reported following transfer of demi-embryos under farm conditions (Schmidt et al. 1992b, Brebacka et. al. 1992). However, higher pregnancy rates (64\%) were achieved following transfer of embryos biopsied for sexing with a bisection method allowing a smaller biopsy to be taken ( 5 cells) and with the embryo remaining inside the zona pellucida (Thibier \& Nibart 1992). Although the presence of the zona pellucida does not seem to influence pregnancy rates for fresh demi-embryos (Seike et al. 1989) it might reduce risks of adhesion or damage of the embryonic cells during further handling until transfer.

There was a significant reduction of the survival rate of biopsied embryos following freezing and thawing based on both developmental capacity in vitro and in vivo. It is generally ac- 
cepted that freezability of embryos is reduced following splitting. Picard et al. (1985) reported pregnancy rates of $23 \%$ for agar embedded frozen-thawed demi-embryos compared to $60 \%$ for fresh embryos. Thibier \& Nibart (1992) report a calving rate of $35 \%$ for biopsied frozen-thawed embryos versus $54 \%$ for biopsied fresh embryos. When biopsy was taken by aspirating of cells after puncturing the zona pellucida by a small glass pipette, the freezability was not significantly reduced compared to intact embryos ( $44 \%$ vs $50 \%$ ) (Schmidt et al. 1992a).

The more pronounced reduction in pregnancy rate of frozen-thawed biopsied embryos obtained in the present study compared to other studies might be caused either by the extensive damage and frequent loss of the zona pellucida or by the reduction of the number of cells due to the relatively large biopsy, or both. The indication that sealing a demi-embryo inside a zona pellucida with an additional zona pellucida increased the post-thaw survival rate (Niemann et al. 1986) suggests that micromanipulated embryos require a physical protection during freezing. On the contrary, Seike et al. (1991), found no differences in post-thaw quality for demi-embryos which were embedded or not embedded in agar or for demi-embryos with or without zona pellucida. The same authors report calving rates of $25 \%$ and $26.7 \%$ for frozen-thawed demi-embryos with or without zona pellucida respectively indicating limited benefit from protection of the embryonic cells during freezing and thawing.

The moderate reduction (not significant) in post-thaw in vitro survival rate for the whole embryos from which the zona pellucida had been removed compared to embryos with an intact zona pellucida ( $52 \%$ vs $68 \%$ ) obtained in the present experiment, supports the suggestion of a different role of the zona pellu- cida in the freezing of intact or biopsied embryos, made by Niemann (1987).

A number of cells (around 10\%) are shown to be damaged due to the splitting procedure (Nibart et. al. 1988). A further proportion of cells will die during freezing and thawing. The fluorescence test has proved to be useful to assess cell viability after freezing and thawing (Niemann 1980). Living mammalian cells accumulate fluorescin when exposed to FDA and the amount of fluorescence is related to enzyme activity and membrane integrity in the cell. The frozen-thawed biopsied embryos tested in the present experiment showed decreased intensity of fluorescence from cells rather than a lack of fluorescence compared to the intact embryos. This may indicate that the freezing and thawing process will to a higher extent reduce the cell activity rather than instantly kill the cells in the biopsied embryos. However, any further conclusions can not be made due to the small number of embryos tested.

Hence the total number of cells after thawing that have the capacity to resume cell division might be too low in some biopsied embryos. Transferred fresh day-7 demi-embryos seemed not have compensated in cell number by day 15 (Albihn et al. 1991). A blastocyst with a too small cell mass may have reduced capability to give proper signals for maternal recognition of pregnancy.

It can be concluded from the present experiment that it is possible to biopsy and transfer embryos under farm conditions and achieve satisfactory pregnancy results. However, if the biopsied embryos have to be frozen, improved biopsy and/or freezing techniques must be used.

\section{Acknowledgement}

This work received financial support from the Royal Swedish Academy of Agriculture and from the Swedish Institute. 


\section{References}

Albihn A, Gustafsson H, Rodriguez-Martinez $H$, Larsson $K$ : Development of day 7 bovine demiembryos transferred into virgin and repeatbreeder heifers. Anim. Reprod. Sci. 1989, 21, 161-176.

Albihn A, Gustafsson H, Rodriguez-Martinez $H$ : Morphology of day-7 bovine demi-embryos and their post-transfer viability. Reprod. Dom. Anim. 1991, 26, 85-87.

Bondioli KR, Ellis SB, Pryor JH, Williams MW, Harpold MM: The use of male-specific chromosomal DNA fragments to determine the sex of bovine preimplantation embryos. Theriogenology, 1989, 31, 95-104.

Brebacka $P$, Huhtinen $M$, Aalto J, Rainio V: Viability of bovine demi- and quarter-embryos after transfer. Theriogenology, 1992, 38, 107-113.

Gordon JW, Gang I: Use of zona drilling for safe and effective biopsy of murine oocytes and embryos. Biol. Reprod. 1990, 42, 869-876.

Herr CM, Reed KC: Micromanipulation of bovine embryos for sex determination. Theriogenology, 1991, 35, 45-54.

Niemann H: Die fluoreszenzmicroskopishe Beurteilung der Entwicklungsfähigkeit früher Embryonalstadien von Kaninchen und Rind mit dem FDA- und DAPI-Test. Inaugural-Dissertation, Hannover 1980.

Niemann H: The role of the zona pellucida in the freezing of bovine embryos. Proc. Application of egg and embryo technologies to domestic animals, Copenhagen, 1987, 14-15.

Niemann H, Brem G, Sacher B, Smidt B, Kräusslich $H$ : An approach to successful freezing of demiembryos derived from day-7 bovine embryos. Theriogenology, 1986, 25, 519-524.

Parrish JJ, Susko-Parrish J, Winer MA, First NL: Capacitation of bovine sperm by heparin. Biol. Reprod. 1988, 38, 1171-1180.

Picard L, King WA, Betteridge KJ: Production of sexed calves from frozen thawed embryos. Vet. Rec. 1985, 117, 603-608.

Schmidt M, Avery B, Smith SD, Purwantara B, Greve $T$ : The freezability of biopsied bovine embryos. Theriogenology, 1992a, 38, 615-621.

Schmidt M, Smith SD, Avery B, Purwantara B, Greve $T$ : Coculture of bovine demi-embryos prior to freezing. Acta vet. scand. 1992b, 33, 237-243.
Seike N, Sakai M, Kanagawa H: Development of frozen-thawed demi-embryos and production of identical twin calves of different ages. J. vet. med. Sci. 1991, 53, 37-42.

Shamsuddin M, Larsson B, Gustafsson H, Rodriguez-Martinez $H$ : In vitro development up to hatching of bovine in vitro-matured and fertilized oocytes with or without support from somatic cells. Theriogenology, 1993, 39, 1067-1079.

Thibier M, Nibart $M$ : Bovine embryo sexing by a DNA probe on the field. Reprod. Dom. Anim. 1992, 27, 29-33.

\section{Sammanfattning \\ Overlevnadskapacitet hos färska och frysta-tinade nötkreatursembryon från vilka biopsi tagits.}

På några celler (biopsi) som tas ut från ett embryo kan man med hjälp av PCR-teknik fastställa om embryot är bärare av vissa gener. Metoden kan t.ex. användas för könsbestämning av embryon. Motivet med försöket var att ta biopsi från embryon med en enkel delningsmetod lämplig för fältförhållanden samt att testa överlevnaden av dessa färska och efter frysning-tining. Intakta färska och frysta tinade embryon samt embryon vars zona pellucida avlägsnats användes som kontroll. Överlevnaden testades genom odling in vitro i 48 timmar, genom uppskattning av fluorescencegrad efter inkubering med diacetylfluorescin (FDA) och efter embryoöverföring till mottagardjur.

Ingen skillnad i överlevnad in vitro sågs beträffande färska intakta embryon och embryon från vilka biopsi tagits och frysta-tinade intakta embryon med eller utan zona pellucida $(70 \%, 60 \%, 68 \%$ respektive $52 \%$ ) men överlevnaden var significant lägre hos frysta-tinade embryon från vilka biopsi tagits $(16 \%)(p \leq 0.05)$. Dräktighetsfrekvensen efter transfer av frysta-tinade biopserade embryon var significant lägre ( $8 \%$ ) än för färska biopserade embryon $(39 \%)(p \leq 0.05)$. Intensiteten av fluorescence var också lägre hos frysta-tinade embryon från vilka biopsi tagits än hos intakta. Slutsatsen av försöket är att den enkla biopsimetoden kan användas om embryona ej ska frysas. Vid frysning måste förbättrade biopserings-metoder alternativt frysningsmetoder användas.

(Received March 1, 1994; accepted April 14, 1994).

Reprints may be requested from: H. Gustafsson, Swedish Association for Livestock Breeding and Production, Eskilstuna, Sweden.

Acta vet. scand. vol. 35 no. 3 - 1994 